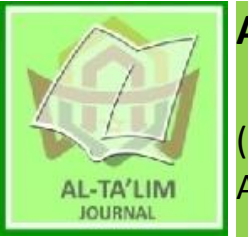

AL-TA'LIM JOURNAL, 27 (1), 2020, (41-57)

(Print ISSN 1410-7546 Online ISSN 2355-7893)

Available online at http://journal.tarbiyahiainib.ac.id/index.php/attalim

\title{
Lecturers' Speech Acts in Arabic Language Learning Interactions at UIN Sulthan Thaha Saifuddin Jambi
}

Received: 05 ${ }^{\text {th }}$ April 2019; Revised: $06^{\text {th }}$ April 2019; Accepted: $27^{\text {th }}$ February 2020

Permalink/DOI: https://doi.org/10.15548/jt.v27i1.597

\section{Yogia prihartini *)}

Universitas Islam Negeri Jambi, Indonesia.

E-mail:

yogia_prihartini@yahoo.com

\section{Wahyudi Buska}

Universitas Islam Negeri Jambi, Indonesia.

E-mail:

wahyudi1000data@gmail.com

\section{*) Corresponding Author}

\begin{abstract}
This study aims to describe the type and function of lecturers' speech acts in the interaction of learning Arabic at UIN Sulthan Thaha Saifuddin Jambi. Where in the classroom, the lecturers had important roles in the teaching and learning process. They always use speech as medium to convey ideas to students. Lecturers are also expected to function as active communicators in Arabic lectures. The interaction that is built by lecturers and students is inseparable from the speech act. A qualitative approach was implemented where the data taken from lecturer utterances in Arabic learning interactions were obtained from Arabic lecturers. Data collection was taken by using non-participant observation technique. Mechanical devices and stationery are positioned as data collection aids. Data analysis includes data reduction, data presentation, and data collection/verification results. The finding showed that the lecturers use five types of speech acts in Arabic learning interactions, namely directive, assertive, co missive, expressive, and declarative acts. The finding also showed that there are social and educational functions used by Arabic lecturers. Social functions consist of four categories, namely, competitive functions, convivial functions, collaborative functions, and conflictive functions. While, the educational function of lecturer speech acts consists of nine types, namely, giving a positive impression of the material, directing focus, inclusive learning situations, exclusive learning situations, expressing specific things, encouraging students to build conclusion, controlling the learning situation, and providing motivation to students. The results indicated that the lecturers' speech acts deal with social problems and learning objectives.
\end{abstract}

Keywords: Speech acts; interaction; Arabic language learning.

How to Cite: Prihartini, Y., \& Buska, W. (2020). Lecturers' Speech Acts in Arabic Language Learning Interactions at UIN Sulthan Thaha Saifuddin Jambi. Al-Ta lim Journal, 27(1). doi:https://doi.org/10.15548/jt.v27i1.597

\section{INTRODUCTION}

In learning interactions, educators use a variety of language acts. Acting language of educators needs to be realized as well as possible in order to improve the behavior and learning performance of students. Follow-up language from educators is used to stimulate the mind and motivate students so that they can build knowledge and learning experiences by themselves. For this reason, educators need to master how to provide information, and master various language acts. It needs to be pursued by educators so that learning interactions can take place dynamically, interestingly, and impressively (Crandall, 2000; Gilmore, 2007; Nurpahmi, 2017).

In the context of classroom interaction, educator languages can be divided into two categories, namely instructional languages and non-instructional. Educator language that is instructional is the language educators used to convey learning material. While the language of non-instructional educators is the language educators used for interests outside of the delivery of learning material (Fillmore \& Snow, 2000; Golombek \& Doran, 2014). For example educators tell 
students to clean the blackboard, take the chalk, move seats, and so forth.

According to Gibson et al. (2002), class interaction is a multi-directional communication event that has special characteristics. This particular characteristic relates to elements of a specific context, as stated by Gillies (2004) namely; (1) participants, (2) settings, (3) topics, (4) nature of messages, and (5) message tones. As participants, educators and students have diverse backgrounds and abilities. This has an impact on the interactions they do. The setting, which includes the setting of place and time setting, is also unique because in different places and times it can cause different interaction situations. Like participants and settings, topics in classroom interaction are also unique because educators and learners can develop them according to learning needs. The nature of the message, which includes messages that are important or not important, urgent and non-urgent, can be immediately adapted to the situation and conditions of ongoing learning. The last context element, namely the tone of the message, includes serious / not serious, cynical / not cynical, humor / not humor, and so on. The tone of the message in the interaction is also unique because it depends on the learning situation (Creese, 2006; Hardman et al., 2008; Martin-Jones, 2000; Sahlström, 2002; Smith \& Higgins, 2006). In certain learning situations messages may need to be delivered in a serious tone, for example concerning difficult learning materials; while in other situations the message may need to be delivered in a tone that is not too serious.

Related to this, in classroom interactions lecturers have a strategic role; that role is related to the formal duties of lecturers as instructors and educators. As instructors and educators, besides being required to be able to direct, guide, provide encouragement, and provide information to learners, lecturers are also required to be able to make / use a variety of media, techniques, and learning strategies for maximum results (Amatari, 2015; Inamullah et al., 2008).
In addition to these strategic roles, according to Reinke et al. (2016), instructors also have three additional roles, namely (1) giving learners freedom to interact with their peers, (2) involving learners in class activities and, (3) ) serve the academic interests of learners as well as possible. The first and second roles refer to the understanding that, as a facilitator, the lecturer organizes activities that allow classroom interaction leading to the development of overall communication competencies. In contrast to the first and second roles, the third role refers to the understanding that the lecturer is the manager of learning material and the main contributor in providing knowledge, factual experience, and communication skills to learners.

Regarding the language acts used in supporting this strategic role, Cross (2010) states the following three things: first, there is a relationship between lecturers' language actions and learning patterns. Second, interactions in the classroom between lecturers and students affect the level of learner's response. Third, communication activities are also raised as feedback on the lecturers' language acts.

As expressed in the research problem, the object of this research study is the type of lecturer language action and its function in the interaction of learning Arabic in the classroom. The object of the study suggests that the status of this study is pragmatic research. In line with the object of study and status, the theories which form the basis of this research work are pragmatic theories, especially the theory of language action; Austin's theory, Searle's illocutionary theory, and Lech's illocutionary function's theory. The Austin language act theory in this case is positioned as the main theory, while the next two theories are positioned as subordinate theories because it is a product of the development of the Austin language theory.

The Austin language act theory states that language action consists of three types, namely locutionary language acts, illocutionary acts, and acts of perlocutionary. 
The locutionary action is the action that is done by the speaker when speaking. Illocutionary acts are actions done by the speaker when conveying intent. The act of perlocutionary is an act done by a speaker that arises as a result of the act of locution and illocutionary act carried out by a speaker.

In the theory of illocutionary acts Searle stated that illocutionary acts consist of five categories, namely (1) assertive action, (2) directive action, (3) commissive action, (4) expressive action, and (5) declarative action. Assertive action is the act of language in which the speaker is bound to the truth of the proposition he states. Directive action is a language act in which the speaker tries to produce an effect in the form of actions taken by the speaker. Commissive action is a language act in which the speaker is bound by the language action which reveals the conditions of successful implementation of illocutionary which results in a match between the contents of the proposition and reality.

In Leech's illocutionary function's theory it is stated that the Leech language action function uses illocutionary functions which consist of four types, namely (1) competitive, (2) convivial, (3) collaborative, and (4) conflictive functions. Speech which functions as a competitive illocutionary implies competition between the illocutionary goals of the speaker and social values (Leech \& Thomas, 2002). Speech that functions illocutionary convivial suggests a journey between the illocutionary goals of the speaker and social values. Speech that functions collaborative illocutionary implies that the illocutionary purpose of the speaker ignores social values. Speech which functions as a conflicting illocutionary implies that the purpose of the illocutionary speaker is contrary to social values.

Austin's language act theory, Searle's illocutionary action theory, and Leech's illocutionary function theory can be operated appropriately to break pragmatic codes, especially regarding lecturers' language actions in classroom interactions (Harnish,
2009; Kibble, 2006). The teacher's speech acts in the interaction of learning Arabic using Arabic as the language of instruction in the learning process at Madrasah schools are very difficult to find, therefore researchers conducted research at UIN Sulthan Thaha Saifuddin Jambi, precisely at Arabic lecturers.

Based on the background in this study, the general problem of this study is: how is the speech act of lecturers in the interaction of learning Arabic at UIN Sulthan Thaha Saifuddin Jambi? The general problem is broken down into two problems as follows: 1) what type of speech act are lecturers using in the interaction of learning Arabic at UIN Sulthan Thaha Saifuddin Jambi? 2) How is the speech act function of lecturers in the interaction of Arabic at UIN Sulthan Thaha Saifuddin Jambi?

\section{Speech Actions in Learning Interactions}

In line with the thinking of Inbar et al. (2001) the function of language as a communication tool consists of transactional functions and interactional functions. Transactional function is a language function that prioritizes the delivery of information content, while the interactional function is a language function that emphasizes social relations and interpersonal attitudes.

In relation to these two language functions, good speakers are not only required to be able to imagine, formulate, organize and express messages, but also feel the level of achievement of the message it conveys. The level of achievement of the message is stated to be maximized if the message delivered by the speaker can be understood by the recipient as the speaker intended (Goel et al., 2009).

According to Origgi \& Sperber (2000) the success of the interaction can be achieved by paying attention to four elements, namely (1) the linguistic element, which is the linguistic element used as a tool to express the message, (2) the paralinguistic element, the element that accompanies speech in the form of attitude (respecting or demeaning) or emotions (like or dislike) of participants of 
speech (3) nonlinguistic elements, nonlinguistic elements are physical elements that support the clarity of messages, such as gestures of facial expressions, and body movements, and (4) metalinguistic elements, are elements related to language that allows speech participants to decide the acceptability and appropriateness of an act of communication. This is closely related to what must be conveyed and how to convey it (Vieira et al., 2007).

The interaction between teacher and student in the learning process is basically the same. In it there is a systematic exchange of behavior that is influenced by the context of communication. The consequence of the exchange of language actions is that various kinds of language actions can be found when the process of learning interaction occurs. The language acts include (1) acts of approval, (2) acts of refutation or refusal, (3) acts of expressing sympathy, (4) acts of debate, (5) acts of diverting conversation or topics, (6) acts of denial, (7) ) acts of praise, (8) acts of congratulation, (9) acts of seduction / flattery, (10) acts of pride, (11) acts of criticism / appraisal, (12) acts of warning, (13) acts of insult, (14) acts of accusation / blame, (15) acts of threatening, (16) acts of reminding, (17) acts of suggesting, (18) acts of encouraging, (19) acts of convincing, (20) acts of affirmation, (21) acts of coercion, (22) acts of commenting or giving reviews, (23) acts of asking questions, (24) acts of amending, (25) acts of reporting and (26) acts of analyzing (Calero, 2005).

Atkins \& Brown (2001) mention that the the conversation form between teacher and students in the classroom interaction are characterized into: (1) teachers' utterances as the initiator of students' utterances, and (2) teachers' utterances as the feedback of students' utterances.

\section{Types of Speech Actions in Learning Interactions}

Specifically, Searle, as quoted by Leech \& Thomas (2002) classifies illocutionary speech acts into five major groups as follows:

\section{Assertive}

This assertive speech act has the function of informing people about something as it is and the speaker is bound to the truth of the proposition being expressed. Example: states, proposes, expresses, opinions, and reports.

This assertive action is commensurate with the kalam habariy in Arabic rhetoric, which is every statement in the form of a statement or information that may contain lies or truth seen from the reference conditions. Kalam khabariy is a speech whose content is reached or the event takes place without having to be related to the speech act. So the speech does not result in something happening. Walfajri (2019) Contoh, tindak asertif dalam memberi penjelasan : Iza yanhi al-muhaadharah ubuk al-atii fi yaumil inaini, ma laa fil alyaumil khami, lianni fii yaumil khami mu'taqidah fi hudhuril muhaadharah.

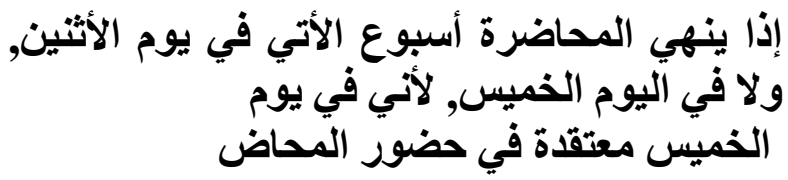

Context: The lecturer explains to his students that the meeting next week is not on Thursday but Monday, because the lecturer has other business to attend to.)

\section{Directive}

The directive speech acts to make the speaker do something. Example: advice, request, order, order, request, demand, give advice, urge, and oppose. This type of illocutionary is often included in the competitive category, because it includes the category of the illocutionary category which requires negative manners (an example of governing). But on the other hand there are also several illocutionary directives that are intrinsically polite, like inviting. By Leech, the competitive illocutionary directive was classified as dispositive. 
Some categories of directive actions are equivalent to the words of insya 'thalaby in Arabic rhetoric which has the meaning of speech acts that demand actions from the interlocutor and the action has not occurred at the time the speech acts take place, such as prohibitions, calls, questions, commands Walfajri (2019) Examples of directive actions are: Haza amrun "ajibun faklan, maa makna faklan (The lecturer asked all students the meaning faklan).

\section{Commissive}

Commissive speech acts are speech acts that express the intention that the speaker will do something contained in the speech. There are two types of commissives namely promises and offers. Contracting and shoals are included in the promising category. This commissive speech act is equivalent to part of the scope of the khair ghairu thalabiy kalam, which is the act of oath and contractual speech. Kalam khabar ghairu thalaby has the meaning of speech acts that do not require the occurrence of an action, such as praise, criticize, express surprise, hope, swear and contract. Examples of commissive acts, (Jaiid wa Jiddan).

\section{Expressive}

Speech acts expressing certain psychological feelings to the person they are talking to, both routine and pure. In expressive, the only intention directed by the speech partner expressed is that the speech partner believes that the speaker has the feeling expressed. The speech partner views that the speaker has the expressed feelings. Examples are greetings, thanking, apologizing, and expressing condolences. Thus, praise, denounce and wonder statements in the gabar-khal khabar khabar are included in the category of expressive acts or acknowledgments (Walfajri, 2019). Example of expressive action: the lecturer greets all students in the class (assalamu'alaikum warahmatullahi wabarakaatuhu).

\section{Declarative}

This speech act illustrates a change in relationship state for example when we resign by saying "I resign", firing someone by saying "you are fired" or marrying someone by saying "I do", or speech act that connects the contents of the proposition with reality, for example, to punish, assign, fire, give names and the like. These actions in this illocutionary almost do not involve the factor of courtesy. Good manners also do not depend on the illocutionary declaration because this type of illocutionary does not have speakers as possessed by private discourse, in other words, speakers who utter declarations use language merely as an outward sign that an institutional action has been carried out.

\section{Speech Actions in Learning Interactions}

In connection with the speech act function, Perry et al. (2002) classifies the speech act function based on six action groups, namely (1) the act of exchanging factual information, which functions to report, for example identifying and stating, (2) acts of exchanging intellectual information, (3) the act of exchanging emotions, serves to express various kinds of emotional feelings, for example feelings of disappointment, pleasure, displeasure, anger, joy, (4) acts of exchanging moral attitudes, which serve to express various moral attitudes and views, for example good/ bad and right/ wrong judgments about certain moral attitudes (5) acts of convincing or influencing, functioning so that the interlocutor performs an action desired by the speaker. (6) Acts of socializing serves to strengthen the relationship between the speaker and the speaker.

The grouping of the Searle speech acts was developed by Grewendorf \& Meggle (2012) into 26 functions, namely (1) the greeting function, (2) the inviting function, (3) the praise function, (4) the congratulatory function, (5) the flatter / seductive function, (6) interrupt function, (7) interrupt function, (8) invoke function, (9) request function, (10) 
expect function, (11) evade function, (12) criticize function, (13) reprimand function, ( 14) warning function, (15) approve function, (16) reject / disprove function, (17) reassure function, (18) report function, (19) influence function, (20) remind function, (21) advise function, (22) the function of asking, (23) the function of sympathizing, (25) the function of expressing condolences, and (26) the function of apologizing.

The two groups of speech act functions are different from the speech act groups according to Leech. According to Leech (2002) the speech act function (Leech uses the term illocutionary function) consists of four types, namely (1) competitive function, implies competition between the illocutionary goals of the speaker and social values. Examples are speakers ordering, asking, demanding, and begging, (2) the convivial function implies a journey between the illocutionary goals of the speaker and social values. An example is offering, inviting, inviting, greeting, thanking, and congratulating, (3) the collaborative function (cooperating) implies that the illocutionary goal of the speaker ignores social values. An example is the speaker claiming to report, announce, and teach, (4) the conflicting function implies that the illocutionary purpose of the speaker is contrary to social values. For example, speakers threaten, accuse, bully, swear and scold.

\section{METHOD}

The approach used in this study is a qualitative approach. Qualitative research tends to be inductive research. With this research it is expected to find a theory based on research findings. Thus, this study does not use the hypothesis as an answer. Theory is structured as a research framework and it is possible that there are changes in accordance with the reality of language use found through data. The results of this study are possible to produce new theories or complement existing theories in accordance with research findings.
Qualitative approaches used in consideration include the following: 1). Retrieval of data from the natural setting that is when the instructor interacts teaching and learning in class, 2). The subject is not too big, namely 4 lecturers of Arabic courses, 3). Researchers as the main instrument that is as the party who determines the classification of language acts of Arabic lecturers found. Judging from the type, this research is also a class research because it has the following characteristics: 1). Using class as a research setting. 2). Focusing on interactions that occur in the classroom.

In research on the language acts of lecturers in the interaction of Arabic language classes in PTKIN Jambi Province, researchers have an important role. This is because researchers act as instruments as well as data collectors. Instruments, besides humans, can take the form of other things such as tape recorders and field notes. But its function is limited to supporting research assignments. Therefore, the presence of researchers in addition is very important in conducting research; also directly see the teaching and learning process carried out by lecturers. In addition to speech acts, the language situation also needs attention. With the researchers who directly follow the teaching and learning process it is expected to avoid data manipulation.

This research data is in the form of verbal data that is bound by the context of communication. Verbal data is in the form of utterances that represent the lecturers' language actions in learning interactions. The subjects of this study were 4 lecturers in Arabic Language at PTKIN Jambi Province. The main instrument of this research is the researcher himself. Researchers as the main instrument are tasked with collecting, analyzing, and presenting data into research results. The researcher uses the observation guidelines, while the data analysis format is related to the types and functions of speech acts in the interaction of Arabic class learning classes at PTKIN Jambi Province. 
The data analysis of this research was carried out in three phases of activities, namely (1) data reduction, (2) data presentation, (3) data collection / verification. The validity of the findings can be seen by the recording of the researcher. The recording is a tape from the interviews, field notes. In that study, researchers also included transcripts from the recordings that had been done, as evidence of the validity of the researchers' findings in this determination, as well as evidence when lecturer language acts occurred in classroom interaction. This is done to avoid manipulation of data or fabricated data and make data unnatural.

\section{RESULTS AND DISCUSSIONS}

\section{Types of Arabic Speech Actions used by Lecturers in Arabic Language Learning Interaction at UIN Sulthan Thaha Saifuddin Jambi}

The Arabic speech acts of lecturers in classroom learning interactions consist of five types, namely (1) assertive speech acts, (2) directive speech acts, (3) commissive speech acts (4) expressive speech acts (5) declarative speech acts. The five types of speech acts are presented as follows:

\section{Assertive Speech Acts}

This assertive speech act has the function of informing people about something as it is and the speaker is bound to the truth of the proposition being expressed (Leech, 2002). Assertive speech acts can be realized in the form of speakers giving comments, as seen in speech D1.2.(2).

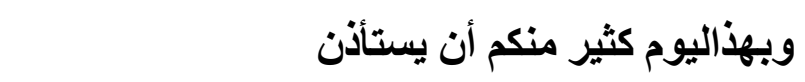

Context: Speaker fills student attendance

Speech D1.2 (2) is a comment to many students who do not attend college. Comments addressed to all class students related to learning activities are also found in the discussion of the material for example on D4.7 (3).

كيف.

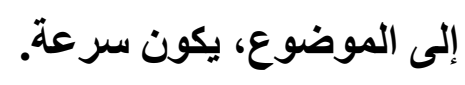

Negative comments are in speech D3.6 (47), Lecturer: I deliberately did not give orders, let's see if you listen or not

Student: Listening to Ustadzah, but that one, is that a series?

Context: The classroom atmosphere is rather noisy, because students do not know what to do

There is also a positive comment in the use of words in example number D1.2.(47).

Context: The lecturer comments after one of the students (named Suci) tells the story of her life until she cries.

The use of the word implies a synchrony between what the speaker wants and the reality he is commenting on. In this case, students were given comments because they showed good performance in telling their life stories. The phenomenon contained in lecturer comments in learning interactions is the presence of neutral comments. This type of comment has the characteristic that comments are only intended to show what is done by students. Lecturers do not compare two things or two parties, lecturers also do not show a certain psychological attitude: satisfied or not satisfied. This neutral comment is exemplified in speech D3.6 (26).

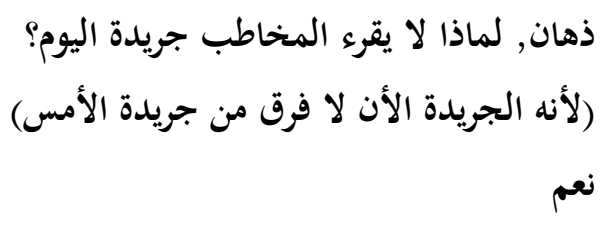

Context: The lecturer gave a comment to one of the students who was confused about how to make a sentence about computers. 
Speech acts giving comments are one of several assertive speech acts. Other speech acts are speech acts showing information, as exemplified in speech D1.1 (16).

Student: What's CPU, Ustadz?

Lecturer: CPU? ما معني CPU, Central?

Student: Central Processor Unit

Lecturer: Central Processor CPU Unit وحدة عملية الحاسب

Student: haha, what is the abbreviation huh?

الأن يقل Lecturer: CPU

Context: The lecturer commented on CPU and mouse in Arabic

In this type of speech, the speaker intends to provide certain information so that others know it. It implies that before information is given, speakers must master what is informed. It is important and must be considered by speakers so that the information conveyed is not wrong.

Other assertive speech acts are the act of agreeing or the speech acts justify the statements of others. This speech act is assertive because it justifies the statements of others. The agreed speech acts are seen in the following example D1.1 (30).

$$
\begin{aligned}
& \text { (قراءة القران كثير فواءد) مرة أخري! قراءة القران كثير } \\
& \text { فوائد) } \\
& \text { (قراءة القران فوائد ها كثير ...كثيرة) } \\
& \text { قراءة القران كثير فوائد } \\
& \text { (قراءة القران فواءدها كثيرة) } \\
& \text { قراءة القران فواءدها كثيرة } \\
& \text { هذا لا بأس، قراءة القران كثير فواءد، لابئس أو قراءة } \\
& \text { القران فواءدها كثيرة }
\end{aligned}
$$

Context: The lecturer corrects sentences made by students

Speech act provides an explanation as an answer to a question also classified as assertive speech act, because the speaker is bound by the truth of the proposition he states. In giving this explanation it is certainly imperative that the speaker is sure of the truth of his proposition so that when the explanation is delivered the speaker understands the explanation of what he stated. The speech act gives the explanation as seen in: D1.2 (55).

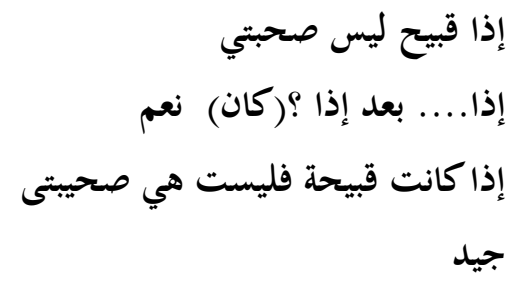

Context: lecturer gives an explanation to students.

Other example speech acts in assertiveness are speech acts stating which examples are seen in speech in numbers D2.5 (2).

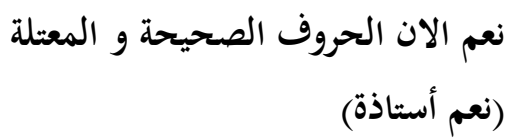

Context: The lecturer stated that he would discuss about al-huruf al mu'talah

The speaker states what he does. It must be in accordance with reality so that when stated, the proposition contained becomes true.

Speech acts express with a tendency to remind, as can be observed in speech in a conversation unitD4.7 (3).

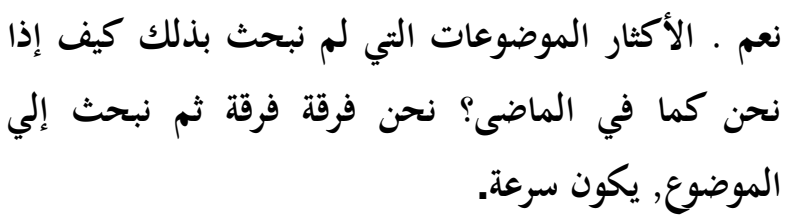

Context: The lecturer will start the discussion with a learning method like yesterday, using groups.

This is also an assertive speech act. Because in line with the tendency to remind, there is a pressure that the speaker must really pay attention to what is spoken by the speaker. Related to this, in emphasizing that, students can determine the main idea because 
the group method has been done at the previous meeting.

Another type of assertive speech act is to allow or allow as in the example in speech D1.2 (28) although due to this speech act the speaker is carrying out something, this speech act is classified as a directive speech act because the initiative to do a speech act is not from the speaker but the speaker. Speakers in this case only allow the speaker to do the things that he will do. D1.2 (28).

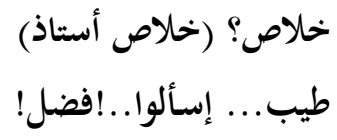

Context: The lecturer invites students who ask questions after hearing a friend's story

Based on the above explanation it can be stated that in the assertive speech act the speaker is bound by the truth of the proposition he states. In accordance with the explanation, assertive speech acts consist of speech acts giving comments, agreeing, confirming others' statements, giving explanations, stating, permitting or allowing.

\section{Directives Speech Acts}

As Leech (2002) stated, directive speech acts are language speech acts that produce effects in the form of speech acts performed by speakers. In other words, in directive speech acts, the speaker orders that certain speech acts take place. As seen in unit D3.6 (9) directive speech acts can be realized in the form of commanding speech acts.

$$
\text { جميتي , تقدمي التلخيص ! }
$$

Context: The lecturer instructs Jumiati to summarize the material that has just been heard.

In this data, directive speech acts are commanding speech acts. Because governing a student named Jumiati, in this case the commanding speech acts are direct because they are delivered in directive sentences and are straightforward or explicit. In addition, it can be addressed to a single speaker, as shown in the speech above. The commanding speech acts can also be addressed to plural speakers, as shown in speech number D1.2 (22).

$$
\text { طيب إسمعوا واسألوا فيما بعد...! }
$$

Context: The lecturer calms the class and asks students to listen, then asks questions after Suci tells the story.

In the conversation unit the speaker is in the plural because it refers to the student in one class. They must listen then ask after the story is over. Like speech D1.1 (57).

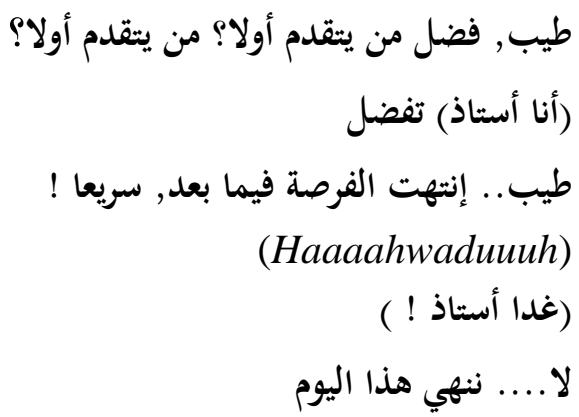

Context: The lecturer emphasizes that the time is over to discuss with each other's conversation partners.

The same conversation is also addressed to plural speakers. The references are the same, namely students in the same class. The difference is that the speaker's identity in speech is unclear. Submission of orders indirectly in addition can be done by using speech in the form of questions; also can be done by speech in the form of statements. Indirect orders that are packaged in the question editor can also be combined with the command editor, as seen in speech D1.2 (32).

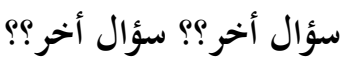

Context: The lecturer asks students who have not asked and other than those who tell stories

In the data, the position of question speech, in other words the order of speech is an additional statement contained in the question. 
Directive speech acts can also be realized in the form of prohibited speech acts. prohibited speech acts can be interpreted as negative governing speech acts in the sense that speakers are told not to do certain things. The directive speech acts in the form of prohibited speech acts can be observed in the following speech. D1.2 (25).

\section{طيب إسمعوا...!}

Context: Lecturers calm class situations, because many students do not listen to their friends tell stories in front of the class.

Indirect prohibitions can also be realized in the form of questions, as seen in the speech.

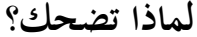

Context: The lecturer asks students who have been noisy and just laugh.

The conversation unit is not intended to ask or ask for information because there is no important information that can be obtained by asking the question. Another form of directive speech acts is reminding speech acts. As the example in D1.2 (56).

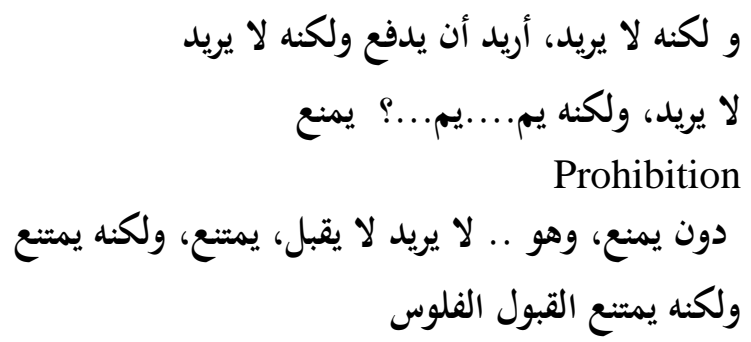

Context: The lecturer repeats the word yam yam to provoke and remind students.

This speech act is realized if someone forgets to do something. In this conversation unit, to remind students who forget? Directive speech acts can also have another form, namely speech acts which provide advice, D1.4 (16).

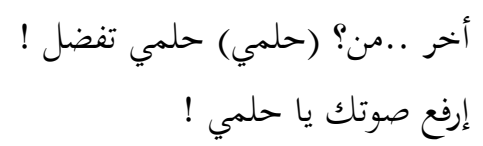

Context: The lecturer suggested Hilmi to raise his voice when telling a story.

This speech act is basically like advising speech act because the speaker wants the storyteller to raise his voice. Based on the foregoing, it can be stated that in directive speech acts, speakers do certain speech acts with the effect of the speaker doing something as intended by the speaker. In accordance with this explanation, directive speech acts consist of commanding, prohibiting, advising, reminding and giving advice.

\section{Commissive speech acts}

In contrast to assertive speech acts that do not have a continued impact in the form of certain activities, commissive speech acts have a further impact in the form of certain activities. In terms of follow-up impacts, commissive speech acts are the same as directive speech acts. However, both are different in terms of the activity actors. If in the directive speech act, the agent of the activity is the interlocutor, in the commissive speech act, the agent of the activity is the speaker.

Commissive speech acts can be realized in the form of promised speech acts, as seen in speech D1.4 (33).

أظن هذا، و في اليوم الأسبوع الأتي في اليوم الإثنين

Context: The lecturer gives an explanation to students about the final assignment of the lecture before the final exam.

In addition to being able to be realized in promised speech acts, commissive speech acts can also be realized in the form of statements which will be followed by speech acts that will be carried out by the interlocutor. Commissive speech acts of this type can be given examples by speech in the following conversation. D2.5. (2). 


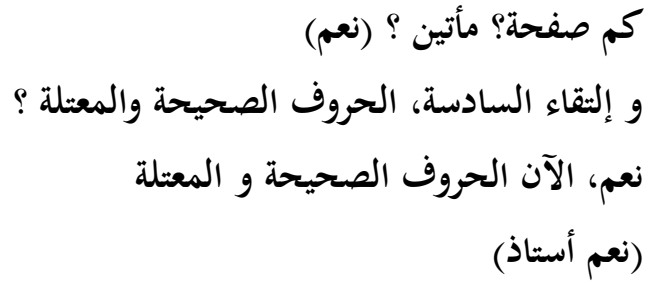

Context: The lecturer asks about the pages and learning themes to be discussed

Based on the foregoing explanation, it can be stated that in the commissive speech act the speaker does a speech act of a certain language with the effect of the speaker going to do a speech act as he intended. In accordance with the explanation, commissive speech acts consist of promising speech acts and states which are followed immediately by certain speech acts.

\section{Expressive Speech Acts}

Expressive speech acts are different from assertive, directive, and commissive speech acts because expressive speech acts express the psychological expression of the speaker on certain matters. This speech act can be realized in the form of speech acts of praise, as for example in D1.2 (12)

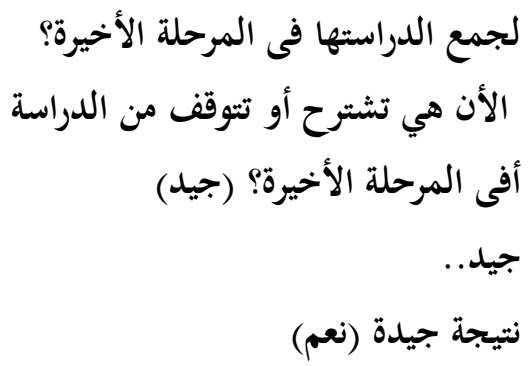

The speech acts of praise can not only be stated in a standard manner (جيد), but can also be expressed with a higher intensity, for example by using the word (جذابة) D1.2 (47).

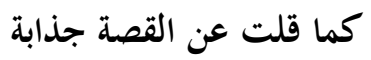

Context: The lecturer praises the truly touching story of the Holy life
Based on the exposure in advance, it can be stated that in expressive speech acts the speaker performs speech acts that as expressive psychological condition. In accordance with the explanation, expressive speech acts consist of acts of praise.

\section{Declarative Speech Acts}

Declarative speech acts are basically speech acts in which the purpose of the speaker is stated in the verb which becomes the predicate of the speech, in this speech act the interlocutor can quickly find out the meaning of the speaker, because the speaker makes his intent explicit.

$$
\text { نحن نبدء }
$$

Context: The lecturer states that he will start reading the text.

Based on the data above, it is stated that in declarative speech acts, speakers do certain speech acts of language which are released through verbs which become the predicate of the speech. In accordance with the explanation, declarative speech acts consist of promising and emphasizing speech acts. Both speech acts are almost the same as commissive speech acts, the difference is that in a declarative speech at the purpose of the speaker is clear because it is mentioned in the verb that is the predicate of the speech.

\section{The Lecturer Speech Function in Arabic Language Learning Interaction at UIN Sulthan Thaha Saifuddin Jambi}

The speech act function of lecturer language can be divided into two types, namely social function and educational function. The social function of lecturer language speech acts is the use of lecturer language speech acts in relation to social objectives, while the educational function of lecturer language speech acts is the use of lecturer language speech acts in relation to their learning fields. 


\section{Social Function of Lecturer Language Speech Acts}

In line with what was stated by Leech (1993), social functions of speech acts can be grouped into four categories, (1) competitive functions, (2) convivial functions, (3) collaborative functions, (4) conflicting functions.

\section{Competitive Function}

In this function, the intention of the speaker competes with social goals. This function can be found in the form of governing speech acts, as seen in speech D1.2 (32)

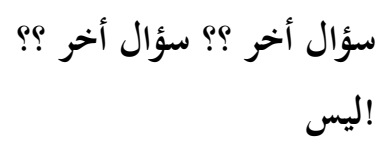

Context: Lecturers open up opportunities to ask students who don't tell stories.

\section{Convivial Function (fun)}

In this function, the intention of the speaker is in line with social goals, for example the speaker praises, as for example in D1.2 (47).

\section{كما قلت عن القصة جذابة \\ (Ciee ehm ehm )}

Context: The lecturer praised Suci because she was able to tell her life story in Arabic.

In the conversation unit, the lecturer gives praise with the intention of pleasing his students, and pleasing others is in line with social goals. Thus, the impact can be predicted that the students who are praised will feel valued and appreciated for their learning activities so as to create feelings of pleasure and satisfaction.

\section{Collaborative Function}

In this function the intention of the speaker is to ignore social goals, for example the speaker asks something, as seen in the utterances in the unit below.

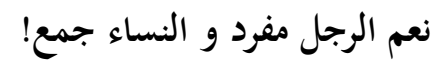

Context: The lecturer asks students to take turns answering together; Mufrod for the boys, jama' for the girls.

Even though the intention of the speaker ignores social goals, the speaker is still bound by the necessity of language, that is, he cannot state things that are not in line with social goals

\section{Conflicting Function}

In this function the intention of the speaker is contrary to social goals. That means that the speaker is clearly in conflict with social goals, for example the speaker scolds the speaker. It can be seen in the following example.

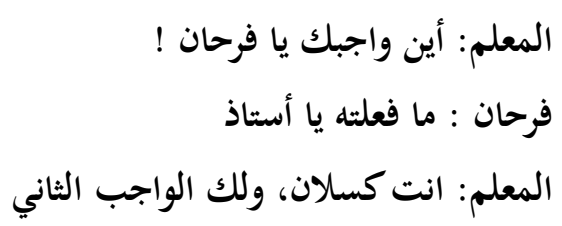

Context: The lecturer scolds the student for not making assignments and giving additional assignments to the student.

\section{Educative Functions of Lecturer Language Speech Acts}

The educative function of the lecturer language consists of nine types, namely (1) giving a positive impression of the material, (2) directing the focus, (3) making inclusive learning situations, (4) making exclusive learning situations (5) expressing specifics, (6) encouraging students associate the material with prior knowledge and or experience and with the phenomena of daily life, (7) encourage students to build conclusions (8) control the learning situation (9) provide motivation to students. The following will explain the educative function of the lecturer's language in detail with the discovery of data in Arabic lecturer communication in lectures.

Creating Positive Impressions on Material 
Many things must be done by the lecturer when learning will begin. One of them is to create a positive impression on the material to be taught. Studies show that students learn more if the lessons are satisfying, challenging, and friendly, and they have a voice in decision making. With such conditions, students more often participate in voluntary activities related to learning material as shown in speech D2.5 (2) -D2.5 (4).

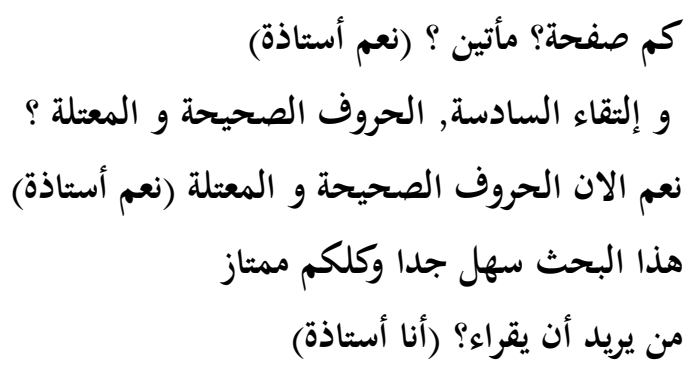

Context: The lecturer asks about the material to be discussed while stating that the material is very easy to learn, and asks who the volunteer wants to read. The atmosphere of the class was vibrant even though the lessons lasted at the last hour.

To make an easy impression, the lecturer can also use other methods, for example by giving an example first as can be observed in speech D1.4 (15).

$$
\begin{aligned}
& \text { يخابر مسرور ؟ (يخابر مسرورة) ما معني خبر مسرور؟ good) } \\
& \text { news) } \\
& \text { يخابر مسرور , ما معني مسرور؟ } \\
& \text { (Making people happy) } \\
& \text { هذا مسرور } \\
& \text { نعم بخبر مسرور } \\
& \text { أنا مسرور هماذ الخبر المسرور، نعه؟ هذا مسرور بهاذ الخخبر }
\end{aligned}
$$

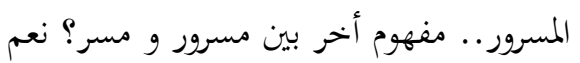

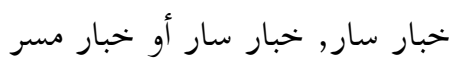

In addition students can make adaptations, analogies, and creations based on existing examples.

Positive impressions, aside from being created by making the material easy to learn, can also be done by conditioning students to be happy in learning it. In this case, the lecturer must know what his students are like. If students are happy, it can indirectly be a motivation for students to learn the material.

\section{Directing Focus}

Another thing that is also important to be considered by lecturers in the lecture process is to direct the focus. In this case as stated learning is double level. In other words, learning happens both consciously and unconsciously at the same time. The brain is always flooded with stimulus, and the brain chooses a specific focus second by second. Although we consciously only pay attention to input one by one, the brain is able to unconsciously pay attention to many things from many sources at once; as such, the lecturer can do a variety of ways, including reprimanding students who behave strangely, for example smiling while he cannot do things that must be done, as shown in the speech.

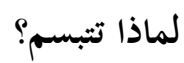

Context: The lecturer asks students who have been noisy and only smile and do not pay attention to the lecture material.

Besides being addressed to specific students, reprimands or appeals can also be done collectively with many students as orientation. As seen in speech D1.2 (42).

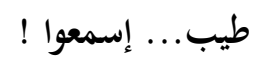

Baik.. dengarkan!

\section{Inclusive Learning Situation}

Inclusive learning situation is also important in learning. Lecturers should avoid affirmative statements, such as "I want you to take out your books, and ask you to collect your homework," because they seem uneducated one. As another example "I am in control and you have to do what I tell you to," So students who have negative associations will respond negatively, for example, dissenting and noisy. 
Provide opportunities for students to do something, for example, refute or comment as shown in DI.2 (68).

$$
\begin{aligned}
& \text { إنتهت الفرصة؟(نعم) طيب كثير منكم من لم يتكلم (نعمو } \\
& \text { نستمر ) نستمر ؟؟ (نعم) }
\end{aligned}
$$

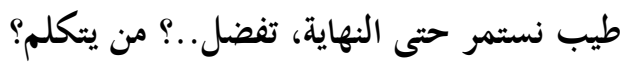

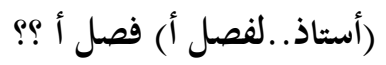

$$
\begin{aligned}
& \text { (أستاذ... لفصل ب) فصل ب ؟؟ }
\end{aligned}
$$

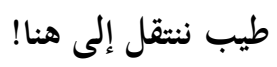

\section{Excluding Learning Situations}

Research shows that the social environment or classroom environment is the main psychological determinant that influences academic learning. Mentioning the names of students one by one is one way to exclude the atmosphere as seen in D1.4 (21).

$$
\begin{aligned}
& \text { إسمه نصرل؟ نعه؟ نصرل (نصرالله) هذا (جيد) }
\end{aligned}
$$

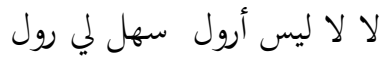

$$
\begin{aligned}
& \text { فضل إسئال ! }
\end{aligned}
$$

Use second-person singular pronouns as can be observed in D2.5 (13)

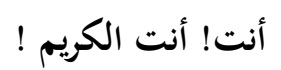

\section{Express specific things to direct understanding}

Expressing specifics is very important in the learning process. So that students do not misinterpret lecturer instructions because the lecturer is not specific. There is an unwritten rule: Save Language. In other words, say what needs to be said with as much clarity as possible as and with as few words as possible.

In expressing specific things or material, lecturers can use methods such as mentioning more specific instructions to avoid confusion as shown in the example below.

$$
\text { سمعتم أم لا؟ (سمعنا أستاذة) }
$$

Lecturer: I deliberately did not give orders, let's see if you listen or not

Student: Listening to Ustadzah, but number one and two, are they a series?

Context: The classroom atmosphere is rather noisy, because students do not know what to do.

Frequent miscommunication occurs due to generalization. Generalization allows others to fill in the gaps with their own understanding. The more specific the request, the greater the students, the more they will do what they want.

Encourage students to associate material with prior knowledge / experience and phenomena of everyday life.

In other words the lecturer contextualizes the learning material; linking material with real things, connecting material with certain things. As seen in D2.5 (36).

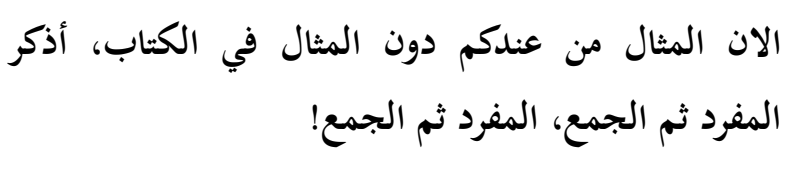

\section{Encourage students to build conclusions}

The next educational function is to encourage students to build conclusions. This function is basically an attempt to find out the level of understanding of students. The conclusions formulated by students have two possibilities, namely right and wrong. This possibility can be seen from the response or comments from lecturers. If the lecturer's response or lecturer's norms are justifying, it will look like the utterance in unit D3.6 (9).
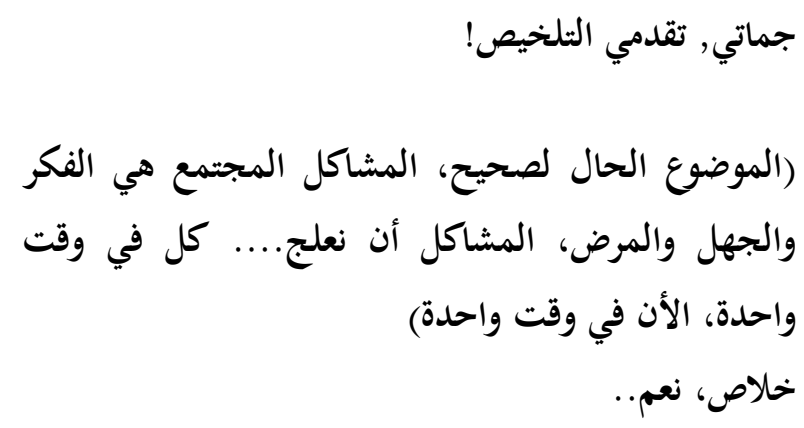


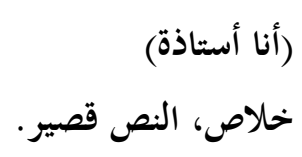

In educational functions, conclusions are true or false are basically not very important; the most important thing is that the lecturer has made the students build their own conclusions based on the concepts they understand. Such conclusions are in line with the principles of constructivism learning. Namely students must build understanding independently.

\section{Controlling the Learning Situation}

Controlling the learning situation is also an important educational function to do so that the learning situation is controlled. With the situation under control, the learning process can run efficiently and effectively so that the input received by students can be maximized. In controlling the learning situation, lecturers can do it in various ways, for example the lecturer asks students to do something, as seen in speech D4.7 (5).

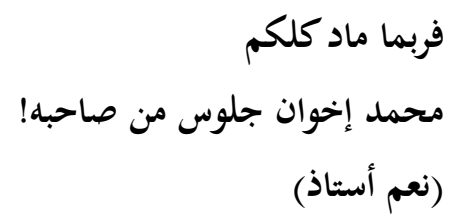

\section{Provide motivation to students}

Another problem that is also important to be done by lecturers is to provide motivation to students. It is expected that every student ideally has an internal motivation, but that sometimes does not happen, so the level of understanding is not optimal. In such conditions, the motivation given by the lecturer through various speech acts of the language he said is very meaningful in improving student learning performance. Motivation given by lecturers to students is basically an external motivation. External motivation can be realized in various ways for example in the form of giving praise before nonmaterial, as seen in D1.2 (24).

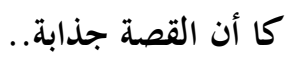

\section{CONCLUSION AND RECOMMENDATION}

The conclusions in this study include: Based on data exposure and research findings as well as discussion of research results, it can be concluded that in learning Arabic, lecturers use five types of language actions, namely directive action, assertive action, commissive action, expressive action, declarative action. The five types of language acts are not the same. Types of directive language acts assume a dominant role, then assertive, commissive, expressive and declarative. Therefore the lecturer must position himself as the facilitator and coordinator of the class.

While in terms of the function of the lecturers' language acts, there are social functions and educational functions. The social function consists of four categories, (1) competitive function, (2) convective function, (3) collaborative function, (4) conflictive function. Among these four functions, the conflicting functions are the least used by lecturers in lectures. While the educative function of the lecturer language consists of nine types, namely (1) giving a positive impression of the material, (2) directing the focus, (3) inclusive learning situations, (4) exclusive learning situations, (5) expressing specific things, (6) ) encourage students to turn on material with prior knowledge and or experience and phenomena with everyday life, (7) encourage students to build conclusions, (8) control the learning situation, (9) provide motivation to students.

In relation to the social function of language action is that social goals are important things to be considered by lecturers. However, because it is in the context of lectures, these social goals must be compatible with their educational goals. Lecturers are also expected to function as active communicators in Arabic lectures. The interaction built by lecturers and students is inseparable from the existence of speech acts. Based on the focus of the speech, locutionary, 
illocutionary, and perlocutionary speech acts are used. Locutionary speech acts are used to inform something. Illocutionary speech acts that occur are classified into assertive, directive, expressive, commissive, and declarative acts. Verbal interactions that occur also cannot be separated from the act of speech perlocutionary, because speech act perlocutionary intended to influence the opposite speech. While in terms of strategy, several types of speech acts are used. Direct literal speech acts using news sentences, questions and commands. In this speech, the news sentence is used to preach, the question sentence is used to ask, and the command sentence is used to govern. Literal indirect speech acts are used to refine commands to interlocutors, such as by using news or question sentences. While direct speech acts are not literally used to criticize, insinuate, and govern. The principle of cooperation is not always obeyed, but it does not mean that the speaker and the interlocutor do not communicate well or are not cooperative. Violation of the principle of cooperation has a specific purpose, for example, to make it easier to provide an explanation. Violations of the principle of cooperation that occurs in verbal interaction is a violation of the rules of the maxim of quantity, maxim of quality, maxim of manner, and maxim of relevance. Verbal interaction of Arabic learning has a journey with Van Ek language function, with the discovery of six categories of functions, namely giving and seeking factual information, expressing and finding out intellectual attitudes, expressing and finding out emotional attitudes, expressing and finding out moral attitudes, persuasion, and socialization.

\section{REFERENCES}

Amatari, V. O. (2015). The instructional process: A review of Flanders' interaction analysis in a classroom setting. Int J Second Educ, 3(3), 4349.

Atkins, A., \& Brown, H. (2001). Sinclair and Coulthard's 'IRF'model in a one-to- one classroom: An analysis. Retrieved June, 29, 2010.

Calero, H. H. (2005). The power of nonverbal communication: How you act is more important than what you say. Silver Lake Publishing.

Crandall, J. J. (2000). Language teacher education. Annual Review of Applied Linguistics, 20, 34-55.

Creese, A. (2006). Supporting talk? Partnership teachers in classroom interaction. International Journal of Bilingual Education and Bilingualism, 9(4), 434-453.

Cross, R. (2010). Language teaching as sociocultural activity: Rethinking language teacher practice. The Modern Language Journal, 94(3), 434-452.

Fillmore, L. W., \& Snow, C. E. (2000). What teachers need to know about language.

Gibson, J. W., Tesone, D. V., Blackwell, C. W., \& Kelsey, R. L. (2002). Managing multi-directional communication in the online classroom. Proceedings. IEEE International Professional Communication Conference, 92-103.

Gillies, R. M. (2004). The effects of communication training on teachers' and students' verbal behaviours during cooperative learning. International Journal of Educational Research, 41(3), 257-279.

Gilmore, A. (2007). Authentic materials and authenticity in foreign language learning. Language Teaching, 40(2), 97-118.

Goel, A. K., Rugaber, S., \& Vattam, S. (2009). Structure, behavior, and function of complex systems: The structure, behavior, and function modeling language. Ai Edam, 23(1), 23-35. 
Golombek, P., \& Doran, M. (2014). Unifying cognition, emotion, and activity in language teacher professional development. Teaching and Teacher Education, 39, 102-111.

Grewendorf, G., \& Meggle, G. (2012). Speech acts, mind, and social reality: Discussions with John R. Searle (Vol. 79). Springer Science \& Business Media.

Hardman, F., Abd-Kadir, J., \& Smith, F. (2008). Pedagogical renewal: Improving the quality of classroom interaction in Nigerian primary schools. International Journal of Educational Development, 28(1), 5569.

Harnish, R. (2009). Internalism and externalism in speech act theory. $L o d z$ Papers in Pragmatics, 5(1), 9-31.

Inamullah, H. M., Hussain, I., \& Din, M. N. U. (2008). Teacher-students verbal interaction at the secondary level. Journal of College Teaching \& Learning (TLC), 5(9).

Inbar, O., Donitsa-Schmidt, S., \& Shohamy, E. (2001). Students' motivation as a function of language learning: The teaching of Arabic in Israel. Motivation and Second Language Acquisition, 23, 297-311.

Kibble, R. (2006). Speech acts, commitment and multi-agent communication. Computational \& Mathematical Organization Theory, 12(2-3), 127145 .

Leech, G., \& Thomas, J. (2002). Language, meaning and context: Pragmatics. In An encyclopedia of language (pp. 105-124). Routledge.

Martin-Jones, M. (2000). Bilingual classroom interaction: A review of recent research i. Language Teaching, 33(1), $1-9$.

Nurpahmi, S. (2017). Teacher Talk In Classroom Interaction. ETERNAL (English, Teaching, Learning, and Research Journal), 3(1), 34-43.

Origgi, G., \& Sperber, D. (2000). Evolution, communication, and the proper function of language.

Perry, N. E., VandeKamp, K. O., Mercer, L. K., \& Nordby, C. J. (2002). Investigating teacher-student interactions that foster self-regulated learning. Educational Psychologist, $37(1), 5-15$.

Reinke, W. M., Herman, K. C., \& Newcomer, L. (2016). The Brief Student-Teacher Classroom Interaction Observation: Using dynamic indicators of behaviors in the classroom to predict outcomes and inform practice. Assessment for Effective Intervention, 42(1), 32-42.

Sahlström, J. F. (2002). The interactional organization of hand raising in classroom interaction. The Journal of Classroom Interaction, 47-57.

Smith, H., \& Higgins, S. (2006). Opening classroom interaction: The importance of feedback. Cambridge Journal of Education, 36(4), 485-502.

Vieira, R., Moreira, Á. F., Wooldridge, M., \& Bordini, R. H. (2007). On the formal semantics of speech-act based communication in an agent-oriented programming language. Journal of Artificial Intelligence Research, 29, 221-267.

Walfajri, W. (2019). Tela'ah Buku Ajar AlBalaghah Al-Wadhihah. Al-Fathin: Jurnal Bahasa Dan Sastra Arab, 3146. 